\title{
IMPLiCATIONS OF CASE MANAGEMENT AND ACTIVE ADJUDICATION FOR JUDICIAL DISQUALIFICATION
}

\author{
Jula Hughes AND PHILIP BRydeN*
}

\begin{abstract}
The judicial role of Canadian judges is changing to allow judges to make trials fairer, more accessible, and more efficient. Along with the changing role of judges has come new tools, including pretrial settlement and case management conferences, and even active adjudication during the course of the trial. However, this new role and the use of its associated tools have the potential to raise an apprehension of bias. This article focuses on recent case law and commentary addressing case management and active adjudication by judges, with the aim of clarifying the boundary between permissible judicial intervention that fosters fairness and efficiency, and impermissible interventions that raise an apprehension of bias. Additionally, we discuss the role counsel can play in helping to avoid concerns of bias from arising.
\end{abstract}

\section{TABLE OF CONTENTS}

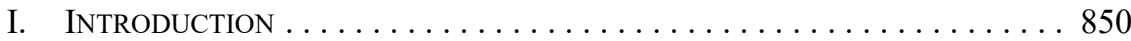

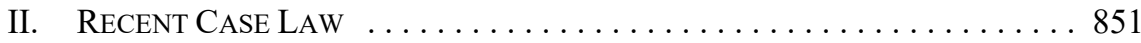

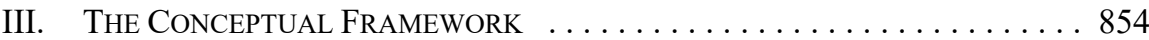

IV. GUIDANCE FROM THE JURISPRUDENCE . . . . . . . . . . . . . . . . . . . 857

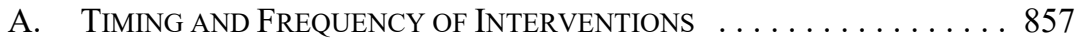

B. MANNER of INTERVENTION . . . . . . . . . . . . . . . . . . . 859

C. ONE-SIDEDNESS OF INTERVENTIONS . . . . . . . . . . . . . . 859

D. TARGET OF THE INTERVENTION $\ldots \ldots \ldots \ldots \ldots \ldots \ldots \ldots$

E. APPELlate CONSIDERATIONS ON THE

F. INTERVENTIONS AIMED AT THE VINDICATION
OF THIRD PARTY INTERESTS $\ldots \ldots \ldots \ldots \ldots \ldots \ldots \ldots \ldots \ldots \ldots 861$

V. AREAS OF CONTINUEd UNCERTAINTY . . . . . . . . . . . . . . . . 862

A. InTERVENTIONS For the PURPOSES OF ASSISTANCE . . . . . . . . 862

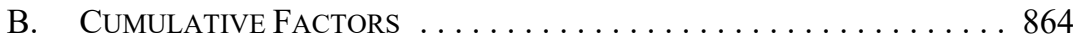

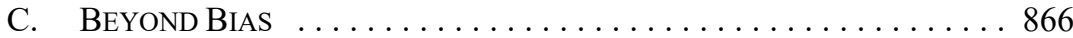

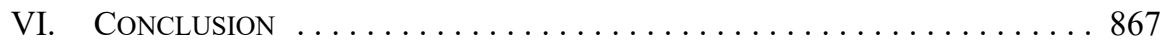

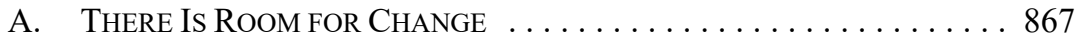

B. PARTY EXPECTATIONS ARE IMPORTANT $\ldots \ldots \ldots \ldots \ldots \ldots 8 . \ldots . \ldots 86$

C. Managing Expectations $\ldots \ldots \ldots \ldots \ldots \ldots \ldots \ldots \ldots \ldots$

D. Avoiding OVERREACH . . . . . . . . . . . . . . . . . . 869

E. The CASe for Rule-BAsed Change . . . . . . . . . . . . . . . . . 869

Dr. Jula Hughes, Professor, Faculty of Law, University of New Brunswick. Philip Bryden, Q.C., Professor, Faculty of Law, University of Alberta, on leave as Deputy Minister, Alberta Justice and Solicitor General. The opinions expressed in this article are those of the authors and do not reflect the views of the Government of Alberta. Thank you to the anonymous peer reviewers and members of the Canadian Association for Legal Ethics for their helpful comments on earlier versions of this article, and to Ashley Godfrey and Remy Ventura, UNB Law, for their able research assistance. 


\section{INTRODUCTION}

Common law lawyers have long held up the idea that "justice be done if the heavens fall." Under this idea of justice, neither expense nor consequence should matter to adjudicators. One aspect of this principled commitment is that "[j] ustice in full takes time."" Both may be justified in cases of grave import, as was the case in Somerset where the Court considered the legal status of a person held in slavery. ${ }^{3}$ A competing consideration has always been that justice delayed is often justice denied, and justice obtained at outlandish costs may simply be unobtainable. Thus, we have come to think that it may not be true in all cases that taking the time for full justice is time well spent, nor does it warrant the financial outlay. There are more disputes seeking resolution in Canadian courts than ever before. Trials take longer and are more expensive, though the number of disputes reaching adjudication is declining. ${ }^{4}$ In the face of very limited judicial resources ${ }^{5}$ and a widely recognized access to justice crisis, ${ }^{6}$ the judicial role is changing to include an enlarged set of tools for making trials fairer, more accessible, and more efficient. These tools range from pretrial settlement and case management conferences to more active adjudication during the trial itself. These changes are not unique to Canada. Other common law and civil law jurisdictions including the United States, the United Kingdom, and Germany have adopted case management in civil cases to promote efficient trials. ${ }^{7}$ Appellate decisions have recognized that "it is no longer possible to view the trial judge as little more than a referee who must sit passively while counsel call the case in any fashion they please." 8

These are important developments and undoubtedly a component of addressing power imbalances, systemic delays, and inefficiencies. However, for judges these new tools also present considerable challenges since judicial interventions have the potential to raise, in the eyes of litigants, and occasionally in the eyes of the reasonable and informed observer, an apprehension of bias. In these cases, appellate courts sometimes describe the judge as having aligned themselves with one of the parties 9 or as having "descended into the fray.".

Somerset v. Stewart (1772), 98 ER 499 (KB) [Somerset], where Lord Mansfield famously held that "[i]f the parties will have judgment, fiat justitia, ruat cœlum, let justice be done whatever be the consequence" (ibid at 509).

Robert Megarry, "Temptations of the Bench" (1978) 16:3 Alta L Rev 406 at 411.

Supra note 1.

Herbert M Kritzer, "Disappearing Trials? A Comparative Perspective" (2004) 1:3 J Empirical Leg Stud 735.

Jula Hughes, "Community-Based Access to Justice: Building a Responsive Justice System in New Brunswick" (2012) 63 UNBLJ 68.

6 Access to Civil \& Family Justice: A Roadmap for Change (Ottawa: Action Committee on Access to Justice in Civil and Family Matters, October 2013), online: Canadian Forum on Civil Justice $<$ www.cfcj-fcjc.org/sites/default/files/docs/2013/AC_Report_English_Final.pdf $>$. One of the principles for civil and family justice reform identified in the Report is that legal processes should be made simpler, more coherent, proportional, and sustainable (ibid at 8).

Steven S Gensler, "Judical Case Management: Caught in the Crossfire" (2010) 60:3 Duke LJ 669; Gunnar Sticken, Die »neue « materielle Prozeßleitung (\$139ZPO) und die Unparteilichkeit des Richters (Köln: Carl Heymanns Verlag KG, 2004); Kenneth M Vorrasi, "England's Reform to Alleviate the Problems of Civil Process: A Comparison of Judicial Case Management in England and the United States" (2004) 30:2 J Legis 361.

$8 \quad R v$ Felderhof (2003), 68 OR (3d) 481 (CA) at para 40 [Felderhof].

9 See e.g. Yukon Francophone School Board, Education Area \#23v Yukon (Attorney General), 2015 SCC 25, [2015] 2 SCR 282 at para 18 [Yukon], citing 2014 YKCA 4, 599 WAC 216 at para 199. 
These phrases are clear in articulating appellate disapproval, but they do not provide very helpful guidance to judges about how to play a more active role without raising concerns about lack of impartiality. It seems to us that the purposes of case management and active adjudication (efficiency, fairness, and access to justice) are potentially undermined when appellate interventions do not give sufficiently clear direction to trial judges. This is because appellate intervention causes further expense and delay as courts have readily acknowledged: "It is with great regret that we must conclude that a new trial should be directed, causing additional expense to the litigants by reason of the conduct of the trial judge who was no doubt endeavouring in good faith to shorten the proceedings." 11

At a systemic level, this additional delay and expense can only be justified if it provides guidance in future cases. However, it may be unrealistic to expect comprehensive bright line rules at this point in time. Lawyers, litigants, and judges in trial and appellate courts alike are relatively new to active adjudication and many have limited experience with case management. Thus, the appropriate boundaries are only now emerging. ${ }^{12}$

In this article, we review the recent case law and commentary on case management and active adjudication with a view to identifying with greater particularity the boundaries between permissible judicial intervention aimed at fostering fairness and efficiency on the one hand, and impermissible descent into the fray on the other. We also canvass the role that counsel might play in helping to avoid bias concerns from arising. We acknowledge that this is an area where the law is likely to evolve for some time to come.

\section{RECENT CASE LAW}

Our point of departure is found in two recent cases released within a couple of months of each other, arising from a civil and a criminal matter in the Ontario and Alberta Courts of Appeal respectively. In both cases, trial judgments were overturned because of what appellate judges considered inappropriate judicial interventions for laudable goals. The cases demonstrate some of the complexities that arise when judges seek to fulfill their role in this changing environment.

The first case was released on 12 November 2014. The Ontario Court of Appeal allowed the appeal in Hazelton Lanes Inc. v. 1707590 Ontario Limited, from a series of judgments and orders of the Ontario Superior Court of Justice on the basis that the trial judge's conduct gave rise to a reasonable apprehension of bias. ${ }^{13}$ It involved a commercial dispute concerning monies alleged to be owed on a lease that the plaintiffs terminated following a breakdown of the business relationship between the parties. The case was somewhat complicated by the counterclaims made by the respondents and their relationship to other litigation between the parties, but counsel originally estimated that the trial should last for three days.

$11 \quad$ Shoppers Mortgage \& Loan Corp v Health First Wellington Square Ltd (1995), 23 OR (3d) 362 at 370 (CA) [Shoppers Mortgage \& Loan].

12 Michelle Flaherty, "Self-Represented Litigants, Active Adjudication and the Perception of Bias: Issues in Administrative Law" (2015) 38:1 Dal LJ 119.

132014 ONCA 793, 326 OAC 301 [Hazelton Lanes]. 
After "about 50 days of court time, consisting of about 30 days of evidence and about 20 days of motions," 14 the trial judge had not reached a decision on the merits but had made a series of orders that were the subject of the appeal. These included a finding that the defendants were in contempt for failure to comply fully with the judge's order for the production of documents, an order striking the defendants' statement of defence and counterclaim, and orders granting the plaintiffs a partial default judgment and costs of $\$ 650,000$ on a substantial indemnity basis. ${ }^{15}$ What began as a relatively straightforward commercial case evolved into a messy dispute where questions concerning the apparently unethical conduct of the parties, and in particular that of the personal defendant, a lawyer who had fallen out with his former client, increasingly became the focus of the proceedings. In allowing the appeal and ordering a retrial, the Court of Appeal acknowledged that the personal defendant had been "a difficult and uncooperative witness" contributed to the trial spiralling out of control." ${ }^{17}$ As a result, the court made no award of costs, either on appeal or in respect of the trial below. ${ }^{18}$

The second decision, $R$. v. Schmaltz, was released on 13 January $2015 .{ }^{19}$ It arose from a sexual assault charge and breach of probation. The accused appealed his conviction because the trial judge had intervened on a number of occasions with a view to protecting the complainant from what the trial judge perceived to be overly aggressive, irrelevant, rape mythological or unnecessary questioning by the defence. The defence alleged on appeal that the interventions occurred in a manner that was prejudicial to the ability of the accused to make full answer and defence. ${ }^{20}$ The Alberta Court of Appeal unanimously rejected the bias claim, but the majority agreed with the defence on the infringement of the right to make full answer and defence. ${ }^{21}$ In particular, the majority expressed concern that the trial judge intervened during the cross-examination of the complainant on whether she had flirted with the appellant, whether she was wearing a bra when the incident occurred, and when defence counsel questioned her on her sobriety and drug use. ${ }^{22}$

Subsequent to these decisions, the Supreme Court of Canada released its decision in Yukon. ${ }^{23}$ Unfortunately, the Court did not take the opportunity to clarify the law on permissible judicial interventions, likely because the facts did not come close to the line. The applicable law on reasonable apprehension of bias is generally not in dispute, ${ }^{24}$ but its application is proving difficult in many marginal situations. ${ }^{25}$ Case management and active adjudication are further instances of the general challenge in application. In Hazelton Lanes, the Ontario Court of Appeal relied on the leading Supreme Court of Canada decisions in

Ibid at para 1

Ibid at paras 1-6.

Ibid at para 111.

Ibid.

Ibid at paras 111-12.

2015 ABCA 4, 320 CCC (3d) 159 [Schmaltz].

Ibid at paras 15-16.

Ibid at para 60 .

Ibid at para 25.

Supra note 9.

Philip Bryden, "Legal Principles Governing the Disqualification of Judges" (2003) 82:3 Can Bar Rev 555.

Philip Bryden \& Jula Hughes, "The Tip of the Iceberg: A Survey of the Philosophy and Practice of Canadian Provincial and Territorial Judges Concerning Judicial Disqualification" (2011) 48:3 Alta L Rev 569. 
Committee for Justice and Liberty v. Canada (National Energy Board), ${ }^{26}$ R. v. S. (R.D.), ${ }^{27}$ and Wewaykum Indian Band v. Canada, ${ }^{28}$ concerning the reasonable apprehension of bias test and the importance those decisions place on the appearance of judicial impartiality as apprehended by the reasonable observer. The Court also drew out a number of general principles from two leading Ontario Court of Appeal decisions in which unsuccessful challenges were made to the impartiality of the trial judge: Chippewas of Mnjikaning First Nation v. Chiefs of Ontario $^{29}$ and Marchand (Litigation Guardian of) v. Public General Hospital Society of Chatham. ${ }^{30}$ The key principles identified were the presumption of judicial impartiality and the onus on the party alleging a reasonable apprehension of bias to produce cogent evidence establishing the allegation on a balance of probabilities. ${ }^{31}$ As a result, the question for the Court was whether the evidence presented was sufficient to displace the strong presumption in favour of the trial judge's impartiality.

The presumption of impartiality was also featured in Schmaltz, but with an important wrinkle. The majority of the Alberta Court of Appeal allowed the appeal on the basis that the fair trial rights of the accused had been breached, and not on the basis that the trial judge's conduct had created a reasonable apprehension of bias. In fact, the Court expressly rejected the bias allegation. However, the Court split on the issue of whether there was a presumption of fairness analogous to the presumption of impartiality.

The majority held that fair trial rights included the right to an impartial tribunal, but noted that it was possible that the right to make full answer and defence could be breached by an impartial tribunal. In cases where the duty of fairness was concerned, the trial judge was not entitled to a presumption of fairness analogous to the presumption of impartiality attaching to judges in the context of bias allegations. In so holding, the majority rejected the contrary view of the Ontario Court of Appeal in R. v. Hamilton. ${ }^{32}$ The dissenting judge would have followed Hamilton and applied a presumption of fairness. ${ }^{33}$

Both decisions fall short of providing essential guidance to trial judges. The Court in Hazelton Lanes did not attempt to draw comparisons between the conduct of the trial judge in this case and judicial conduct that did or did not give rise to a reasonable apprehension of bias in other cases. This is typical of the jurisprudence in this area, including the recent decision of the Supreme Court in Yukon, ${ }^{34}$ and as a result, it is often difficult to discern in marginal cases why the impugned conduct of some trial judges creates a reasonable apprehension of bias whereas that of other judges fails to do so.

The Court in Schmaltz refrained from resolving how to reconcile the obligation to protect complainants from discriminatory or abusive lines of inquiry that feed into rape mythological

[1978] 1 SCR 369

[1997] 3 SCR 484 [RDS].

2003 SCC 45, [2003] 2 SCR 259 [Wewaykum Indian Band].

2010 ONCA 47, 265 OAC 247 [Chippewas] at paras 221-64, leave to appeal to SCC refused, 33613 (8 July 2010).

(2000), 51 OR (3d) 97 at para 131 [Marchand], leave to appeal to SCC refused, 28379 (27 September 2001).

Hazelton Lanes, supra note 13 at para 64, citing Marchand, ibid at para 131.

2011 ONCA 399, 271 CCC (3d) 208 at paras 29-31 [Hamilton].

Schmaltz, supra note 19 at paras 24 (majority), 65 (dissent).

Supra note 9 . 
reasoning with the obligation not to interfere with defence counsel's strategy. In other words, it left open the question about what a trial judge should do when the strategy of defence counsel is to pursue lines of inquiry that relate to rape mythological reasoning. In this case, the defence pursued a line of questioning regarding the potential state of intoxication of the complainant. The defence also pursued the idea that the complainant had not responded in an appropriate way to the alleged sexual assault by not fighting back during the assault and by waiting a few hours before reporting it.

\section{The Conceptual Framework}

In this article, we hope to advance some suggestions to assist lawyers and judges to better understand the appropriate boundaries of judicial intervention into the conduct of cases. Since the techniques and tools used in case management and active adjudication overlap and are evolving, we begin by offering working definitions of these key terms.

We use the term case management to refer to the procedural management of a matter before a court, whether such management is undertaken by the trial judge or a case management judge or a master, and whether it is undertaken as part of a mandatory case management rule or on consent. Case management may be focused on pretrial steps and would typically include case conferences, settlement conferences, and court-based mediation. Particularly in family court, it may also include post-trial and implementation management.

Active adjudication encompasses a range of techniques where adjudicators take a more active stance by altering the format of the hearing, asking questions, offering preliminary conclusions, and so forth. In her recent paper, Michelle Flaherty has argued that active adjudication is one of the appropriate responses of an administrative justice system that is experiencing an ever increasing participation of self represented litigants. ${ }^{35}$ She describes an array of techniques available to administrative decision-makers ranging from limited assistance in an essentially adversarial setting to transformation into a hearing that strongly resembles inquisitorial modes of adjudication. Lorne Sossin has described active adjudication as a "mid-point"; a kind of halfway house between adversarial and inquisitorial modes of adjudication. $^{36}$ In Flaherty's view, the purpose of employing these techniques is fundamentally related to enabling the effective participation of self-represent parties. She acknowledges, however, that adjudicators walk "a very fine line",37 between facilitation of participation and taking on an advocacy role for the self-represented party.

Administrative tribunals have used active adjudication techniques for years and most of the reported case law on bias arising expressly from active adjudication stems from the administrative context. That said, there is now a considerable body of jurisprudence that acknowledges that judges are not required to be passive participants in the hearings over

Lorne Sossin, "Human Rights, Access to Justice \& Innovation" (Paper delivered at the Osgoode Hall Law School's Remedying Discrimination: A Symposium on the Ontario Human Rights Review, 25 January 2013) [unpublished], online: <https://ifls.osgoode.yorku.ca/what-we-do/remedying/>. Supra note 12 at 122. 
which they preside, ${ }^{38}$ and that they may in some circumstances be expected to take an active role, particularly in relation to self-represented litigants. ${ }^{39}$ It would be incorrect, however, to think of active adjudication as a response only applicable in litigation involving inherent inequalities of power or resources. Complex commercial litigation involving multiple represented parties commonly requires case management, both as a preliminary matter and may require active adjudication to steer the trial to an efficient conclusion. Additionally, active adjudication techniques may be useful for ensuring the legally cognizable interests of third parties. Finally, both case management and active adjudication can be employed to constrain participation by the parties in order to ensure that the court time and resources devoted to a case are proportionate to what is at issue in the dispute.

Are the bias concerns that arise in case management and active adjudication qualitatively different from those traditionally seen in adversarial proceedings? In our view, this is not the case. In an earlier paper, we argued that the existing case law on recusal can be rationalized into six categories of situations. ${ }^{40}$ They are (1) personal interests of a financial nature; (2) personal interests of a non-financial nature in a current relationship; (3) past associations with litigants or their representatives; (4) prior judicial involvement with litigants; (5) extrajudicial knowledge of or involvement with the litigation itself; and (6) statements or conduct that might indicate pre-disposition.

While all of these situations may incidentally arise for case management judges or masters, and judges using active adjudication techniques, this article is concerned with two issues in particular that are conceptually tied to case management and active adjudication, prior judicial involvement with litigants for case management, and statements or conduct that might indicate pre-disposition for active adjudication. In using our existing conceptual framework, we indicate agreement with jurisprudence that has suggested that the test and applicable law and principles for recusal in the context of case management and active adjudication are the same as in any other cases. ${ }^{41}$

The difference is not in the approach judges and masters should take, rather, it lies in the frequency with which these concerns are likely to arise in these contexts. The effect of case management is that the parties will work with and be subject to the decisions of the same judge or master over a period of time. This means that case management is a systemically entrenched form of what courts have occasionally described as the repeat customer phenomenon, such as the repeat encounter between an adjudicator and a litigant.

Active adjudication techniques mean that litigants have more opportunity to hear what their adjudicator may be concerned with or thinking about. Since the policy rationales for

Felderhof, supra note 8; Quiroa v Canada (Minister of Citizenship \& Immigration), 2005 FC 271, 30 Admin LR (4th) 316 [Quiroa]; Wayne Gorman, "Reasonable Apprehension of Judicial Bias in Trial Proceedings" (2009) 55:1 \& 2 Crim LQ 46. Judge Gorman provides an account of a number of decisions characterized as excessive intervention. In our view, his account demonstrates the difficulty of discerning guidance for future cases from the existing jurisprudence.

39 Davids v Davids (1999), 125 OAC 375 (CA) [Davids]; Wagg v R, 2003 FCA 303, [2004] 1 FCR 206; Dhaliwal $v$ Canada (Minister of Citizenship and Immigration), 2011 FC 201, 95 Imm LR (3d) 142 [Dhaliwal].

$40 \quad$ Bryden, supra note 24 at 574

41
Dahlseide v Dahlseide, 2011 ABQB 696, 2011 ABQB 696 (CanLII); Airco Aircraft Charters Ltd v Edmonton Regional Airports Authority, 2013 ABCA 387, 561 AR 384 [Airco Aircraft Charters]; Control \& Metering Ltd v Karpowicz (1994), 17 OR (3d) 431 (Ct (Gen Div)) [Karpowicz]. 
case management and active adjudication are closely related, it is not surprising that masters and case management judges engage in active adjudication techniques. These factors together with the relative novelty of active adjudication result in a greater frequency of bias concerns and recusal motions.

Making the justice system more efficient, effective, accessible, and proportional are closely related objectives of ongoing law and court reform efforts. Case management and active adjudication are likely to be part of any toolbox for achieving these objectives. That means that we are likely to see more rather than less of these techniques. Part and parcel of these policy developments is an overarching objective of giving Canadians confidence in the justice system. It would be ironic if concerns over bias and recusal were to undermine these reforms, given that impartiality is ultimately underpinned by a requirement for credibility and legitimacy.

Indeed, courts have generally agreed that case management and active adjudication techniques do not, without more, give rise to a reasonable apprehension of bias. ${ }^{42}$ In a recent presentation, it was argued that contexts and institutional design features with frequently arising bias concerns warrant consideration whether the issue is susceptible to bright-line rulemaking. ${ }^{43}$ Case management is a further example of such a context and the approach of legislatures has been to incorporate case management into their respective Rules of Court. This has informed the approach of judges to potential recusal situations. For example, in Karpowicz, the Ontario Court (General Division) considered whether the fact that a case management judge was required under the Rules to dispose of all motions brought in a managed action created a reasonable apprehension of bias. ${ }^{44}$ The Court concluded that it did not as long as the case management judge did not go beyond what was mandated in the Rules.

It appears to us that there is also implicit judicial recognition that the benefits of case management and active adjudication in terms of efficiency and accessibility of the courts must be weighed against any potential benefits and detriments of a highly sensitive application of the reasonable apprehension of bias test. In this vein, courts have generally agreed that judicial interventions designed to promote efficiency do not give rise to a reasonable apprehension of bias. ${ }^{45}$ Similarly, it is appropriate for judges to seek to focus the inquiry, to uncover evidence that would crystallize issues, to clarify an unclear answer, to resolve a potential misunderstanding of the evidence, to safeguard the interests of third parties, and to correct inappropriate conduct by counsel or witnesses. ${ }^{46}$ Reasonable Apprehension of Bias," (2004) 29:1 \& 2 Adv Q 102 at 115-16, for a more cautionary view suggesting that the proper role of judges requires strict limits on judicial intervention.

43 Jula Hughes \& Philip Bryden, "Empirical and Comparative Approaches to Judicial Disqualification: The Case for Limited-Scope Statutory Frameworks" (Conference Paper delivered at the International Legal Ethics Conference VI, City University London, 2014) [unpublished].

Supra note 41. See also Mazumder v Bell Canada, 2005 CanLII 30333 (Ont Sup Ct J) [Mazumder]. Conway v Barbaree, 2010 ONSC 2073, 2010 ONSC 2073 (CanLII) at para 12.

Schaer v Barrie Yacht Club (2003), 108 OAC 95 (Ont Sup Ct J (Div Ct)). 


\section{GUIDANCE FROM THE JURISPRUDENCE}

In the next section, we explore what guidance can be gleaned from the jurisprudence about the line between active adjudication and case management on the one hand and entering into the fray on the other. We had indicated earlier that the courts in Hazelton Lanes and Schmaltz do not provide much assistance on how judges should reconcile the demands of efficiency and accessibility with the demands for impartiality.

Despite this, there are some factors that have been somewhat consistently considered by appellate courts in cases involving judicial intervention. As we will see, some of these factors risk retrenching courts into more passive modes of adjudication.

\section{A. TIMING AND FREQUENCY OF INTERVENTIONS}

The first of these factors concerns the timing of a trial judge's interjections or observations that are considered by one of the parties to be offensive. While it is true that a reasonable apprehension of bias can be found as a result of comments found in reasons for judgment, ${ }^{47}$ appeal courts tend to be more concerned about statements made partway through a hearing that suggest that a trial judge has made up his or her mind without considering all the evidence. ${ }^{48}$ At the end of the day, trial judges have a duty to assess the evidence that is presented to them and it would be inappropriate for us to ask them to shrink from identifying false statements or misconduct, even though doing so may be hurtful for the person whose conduct or statements are being criticized. Nor is it realistic to expect that trial judges will not have tentative views, both at the start of the hearing and as evidence is being adduced.

Judges can expect heightened sensitivity to their interventions in cross-examinations, and absent a need to protect a witness from abuse, they may be well advised to keep interventions into cross-examination to a minimum, even if this comes at a loss of efficiency. At the very least, a judge should be cognizant of the fact that interventions, however well-intentioned, also have the potential to prolong or even derail a trial, particularly if the judicial intervention takes on the style of cross-examination. This is illustrated in Hazelton Lanes. During the course of the lengthy cross-examination of the personal defendant, the trial judge interjected to pose his own questions to the witness. His initial statement to the witness in respect of a particular piece of testimony was that "your explanation, with respect, defies common sense. Now, I want to give you a chance to rethink it." 49 The judge then attempted to convince the witness to admit that a scheme in which he paid the plaintiff an inflated rent that would then be rebated through payments for legal services that were never rendered was inevitably undertaken for an improper purpose. The effect of this intervention, if not its intent, was to complicate and prolong rather than streamline the proceeding, and to leave in the mind of a reasonable observer concerns about the impartiality of the judge.

The focus for the trial judge is to maintain both the reality and the appearance of being open to persuasion throughout the trial. Appellate courts are particularly sensitive about behaviour that indicates that a trial judge has rejected a key witness' evidence before the 
witness has had a chance to complete his or her testimony ${ }^{50}$ or dismissed an argument before a party has been able to advance its position. ${ }^{51}$

Active adjudication is often thought to be most effective when adjudicators set the tone and mode of hearing early. This may run counter to the requirement that judges refrain from early intervention so as to preserve an appearance of impartiality. It may not always be possible to entirely resolve this tension, but Flaherty suggests some techniques for reconciling the objectives of efficient and accessible adjudication with an appearance of impartiality based on her extensive experience as an adjudicator. These include a preliminary discussion with the parties to promote "buy-in," 52 obtaining consent from the parties for active adjudication, ${ }^{53}$ ensuring plentiful opportunities for parties to correct or clarify the preliminary understanding on a submission or piece of evidence, and providing procedural guidance. $^{54}$

Fundamentally then, it is important for trial judges who intervene in trials, particularly in the early stages and during testimony, to maintain an impartial stance even as they assist the parties in presenting their case efficiently and effectively. This is reflected in the appellate jurisprudence.

Appellate courts seem to give more leeway to trial judges who are attempting to focus the hearing by letting counsel know that the judge considers certain lines of questioning or argument to be important and others to be unproductive. ${ }^{55}$ This is true for civil and criminal matters. However, even in cases where the parties could clearly benefit from some direction, it is important to remain sensitive to fairness considerations. In Schmaltz, the majority of the Alberta Court of Appeal thought that the judicial intervention assisted the witness in tailoring her evidence, rendering the trial unfair. ${ }^{56}$ This could have been avoided by briefly excluding the witness.

$R v$ Huang (Y), 2013 ONCA 240, 115 OR (3d) 596 [Huang]. In Huang, the trial judge's interjection partway through cross-examination of the accused indicating that the accused should seek instruction from counsel on the consequences of perjury indicated that the judge had predetermined the critical issue of the credibility of the accused without hearing all of his testimony, and thus gave rise to a reasonable apprehension of bias.

$51 \quad$ See $R v Y(F), 2011$ NBCA 86, 378 NBR (2d) 37 (the trial judge's rejection of anticipated submission that a conditional sentence would be appropriate before counsel had an opportunity to make it gave rise to a reasonable apprehension of bias); Mitsui \& Co (Point Aconi) Ltd v Jones Power Co, 2001 NSCA 112,196 NSR (2d) 118 (a reasonable apprehension of bias was found where the trial judge concluded that the meaning of a disputed memorandum of understanding had been established by an earlier decision without hearing submissions on this issue). See also Shoppers Mortgage \& Loan, supra note 11.

$52 \quad$ Flaherty, supra note 12 at 127.

$53 \quad$ Ibid. This is trickier territory for judges as they must not only avoid an appearance of bias, but also avoid an appearance that they are fishing for a waiver of bias.

$54 \quad$ Ibid at $128-29$

55 In $R$ v Baccari, 2011 ABCA 205, 510 AR 301, the Court observed:

During argument, trial judges are not precluded from commenting on evidence or attempting to focus the argument on issues of particular concern to the trial judge. Give and take between a trial judge and counsel may be robust but observations made by a trial judge during argument are not pronouncements.... A trial judge is not precluded from voicing concerns about the evidence. Nor is a trial judge precluded from directing counsel's attention to the real issues in the case. Trial judges are not expected to be manikins (ibid at para 24, citing $R v$ Hodson, 2001 ABCA, 281 AR 76 at paras 33, 35; $R v$ WFM (1995), 169 AR 222 at para 10 (CA)).

See also Airco Aircraft Charters, supra note 41 at paras 20-24 where the case management judge's questions to counsel for the City seeking responses to issue of improper motivation for expropriation raised by one of the parties did not give rise to a reasonable apprehension of bias. 


\section{B. MANNER OF INTERVENTION}

A second factor is the way that a trial judge approaches the questioning of a witness. Trial judges are certainly entitled to question witnesses in order to ensure that they understand the testimony that is being given. ${ }^{57}$ Moreover, there are some types of proceedings, such as small claims proceedings where parties are typically unrepresented, ${ }^{58}$ or child apprehension proceedings where the court has a special role in protecting the best interests of the child, ${ }^{59}$ where it is both typical and acceptable for judges to play a more interventionist role while maintaining their impartiality. This being said, it becomes problematic if it appears that the trial judge is slipping into the role of counsel by challenging or cross-examining the witness. ${ }^{60}$ Appellate courts are likely to become concerned if the trial judge appears to take a leading role in questioning a witness by asking questions before cross-examination has commenced $^{61}$ or by interjecting repeatedly. ${ }^{62}$

There will be circumstances in which it is not only appropriate but necessary for trial judges to intervene and ask questions of witnesses in order to ensure that they understand the testimony the witness is offering. This may be particularly important where one or more parties are self-represented. Where parties are represented by counsel, however, it will generally be preferable for a trial judge to reserve his or her questions until counsel has concluded in order to avoid appearing to usurp the role of counsel. In addition, trial judges should normally use questions to ensure that they understand evidence rather than as a way of attempting to evaluate or test evidence.

\section{ONE-SIDEDNESS OF INTERVENTIONS}

A third factor concerns the trial judge's perception of favouritism because of statements made $^{63}$ or evidentiary or procedural rulings that favour one party over another. ${ }^{64}$ It is 50-58 [Metis Child].

See Richardson $v$ Hancock, 2013 SKQB 90, 415 Sask R 269 at para 24; Garry v Pohlmann, 2001 BCSC 1234,12 CPC (5th) 107 at para 52; Classic Super Seamless Exteriors (1988) Ltd v Kaushik, 2005 SKQK 457, 48 CLR (3d) 101 at paras 38-43.

$59 \quad$ Metis Child, supra note 57 at paras 51-53.

60 James $v$ Minister of National Revenue (2000), 190 FTR 159 (FCA).

$61 \quad$ See the comments in Metis Child, supra note 57 at paras 73-75.

62 $R v$ Valley (1986), 26 CCC (3d) 207 (Ont CA), leave to appeal to SCC refused, 19800 (25 April 1986); $R v$ MacDonald (DR), 2001 ABQB 796, 300 AR 31.

63 See Bowerman v Ferster (1986), 46 Sask R 236 (QB) (a reasonable apprehension of bias was created when the trial judge referred to a party as "my old friend" at the commencement of his testimony at para 6).

64 See Byrne v Cave (1992), 74 BCLR (2d) 369 (CA) (new trial ordered where trial judge interfered by preventing cross-examination of witness on key issue upon which decision was based). Judicial interventions that appear to be one-sided are particularly likely to be problematic if the trial judge's participation betrays attitudes that would be liable to censure in their own right. For example, in $R v$ Wagar, 2015 ABCA 327, 2015 ABCA 327 (CanLII) [Wagar], the Alberta Court of Appeal ordered a new trial in a sexual assault case where the trial judge's interjections and reasons suggested to the Court of Appeal that he had relied on discredited sexual stereotypes and myths in dealing with the evidence. For a more detailed analysis of this case, see Alice Woolley, "When Judicial Decisions Go from Wrong to Wrongful: How Should the Legal System Respond?" (3 November 2015), ABlawg (blog), online: $<$ ablawg.ca/when-judicial-decisions-go-from-wrong-to-wrongful-how-should-the-legal-systemrespond/>. 
particularly important that judges apply rules even-handedly as between the parties. ${ }^{65}$ In both Hazelton Lanes and Schmaltz, the majority of interventions affected one side only. This does not mean, of course, that the interventions were biased. Instead, judges are required to deal with each issue on its merits. ${ }^{66}$ What appellate courts are looking for is therefore not a tally of successes, but whether there is a pattern of decisions that suggests influences other than the applicable law and available evidence.

Even then, there is some margin for error. The mere fact that an appellate court believes that a trial judge may have erred in making evidentiary or procedural rulings is not sufficient, in and of itself, to call the trial judge's impartiality into question. ${ }^{67}$ There must be something about the pattern of rulings that suggests that they flow not merely from an incorrect appreciation of the relevant law or facts but from a failure of the trial judge to act in an impartial manner.

\section{TARGET OF THE INTERVENTION}

A fourth consideration is the person toward whom the challenged conduct is directed. A reasonable apprehension of bias may be based on a trial judge's critical comments directed toward counsel ${ }^{68}$ or toward a witness who is not a party, ${ }^{69}$ as well as comments directed toward the parties themselves. However, appellate courts seem to give trial judges more leeway in their criticisms of counsel ${ }^{70}$ or expert witnesses ${ }^{71}$ than they do to criticisms of parties, particularly if those criticisms are levelled while the party is still in the course of testifying. $^{72}$

See e.g. Taylor v Eisner Cancade and Clarke (1993), 105 Sask R 283 (CA), where the Saskatchewan Court of Appeal found that a new trial was necessary when the trial judge had raised the parol evidence rule with respect to evidence sought to be adduced by one side but not when the other side sought to introduce similar evidence. Conversely, the fact that a trial judge has attempted to be even-handed when reining in excessively antagonistic behaviour by counsel will help to justify occasional remarks by a judge that might otherwise seem to be problematic. See Marchand, supra note 30 at para 168.

66 See e.g. Mazumder, supra note 44.

67 See Broda v Broda, 2001 ABCA 151, 286 AR 120 at paras 13-16.

68 See $R v$ Curragh Inc, [1997] 1 SCR 537 (a reasonable apprehension of bias was found when the trial judge telephoned the Attorney General's staff to complain about the Crown Attorney's conduct of the case and to seek his removal from the case); Nazarewycz v Dool, 2009 ABCA 70, 448 AR 1 at paras 74-78 (the trial judge's repeated criticisms of counsel and suggestion that his client consult new counsel gave rise to a reasonable apprehension of bias); Yukon, supra note 9 at paras 51-62 (the trial judge's disparaging comments directed at counsel contributed to the appeal court's finding of a reasonable apprehension of bias).

$69 \quad$ See Lloyd $v$ Bush, 2012 ONCA 349, 110 OR (3d) 781 [Bush] (where the trial judge's unsubstantiated assertion that the expert witness's testimony disputing the accuracy of municipal records amounted to an allegation of fraud on the part of the defendant municipality gave rise to a reasonable apprehension of bias).

70 See supra note 68. See also Scheidt v Scheidt, 2014 ABCA 24, 566 AR 303 at paras 27-32 (the case management judge's criticisms of counsel in the presence of their client was inappropriate but in the circumstances did not give rise to a reasonable apprehension of bias); $R v$ McQuaid (1996), 156 NSR (2d) 182; Authorson (Litigation Guardian of) v Canada (Attorney General) (2001), 17 CPC (5th) 274 (Ont Sup Ct J), aff'd (2002), 32 CPC (5th) 357 (Sup Ct J (Div Ct)); DDP v HMTQ, 2009 NWTSC 14, 81 MVR (5th) 217 (the appeal Court found that the trial judge's repeated expression of annoyance at counsel's submissions was unfortunate, but given the entire context, it did not give rise to a reasonable apprehension of bias). For an example of judicial criticism of counsel that crosses the line into bias see Yukon, supra note 9 at para 10.

71 See Miglin v Miglin (2001), 53 OR (3d) 641 (CA), rev'd 2003 SCC 24, [2003] 1 SCR 303 (the trial judge's comments during the testimony of an expert witness in a family proceeding indicated that the judge was skeptical about aspects of the expert's testimony but did not give rise to a reasonable apprehension of bias).

$72 R \vee$ Brouillard, [1985] 1 SCR 39 at 48; Huang, supra note 50. 


\section{E. APPEllate Considerations ON THE MERITS OF THE INTERVENTION}

A fifth factor is the extent to which an appellate court considers the trial judge's comments that are under review to be well founded, on the one hand, ${ }^{73}$ or possibly ill-conceived on the other. $^{74}$

As stated above, this is not to suggest that appellate courts are likely to accede to a challenge to a trial judge's impartiality simply because they have some questions about whether or not the judge was correct in his or her assessment of the facts under consideration. Questions about the trial judge's impartiality tend to come into play where the appellate court is persuaded that the trial judge has mistakenly come to a conclusion without giving due regard to the possibility that a full consideration of the evidence might lead to a different result.

\section{F. INTERVENTIONS AIMED AT THE VINDICATION OF THIRD PARTY INTERESTS}

In some cases, the interests of third parties may have to be safeguarded, including in criminal cases where complainants appear as the Crown's witnesses, but are unrepresented, or in child apprehension proceedings where the court has a special role in protecting the best interests of the child. ${ }^{75}$ This creates an incentive for judicial intervention that may run counter to the fair trial protections afforded to accused persons, parents, and so on.

The degree to which third party considerations may warrant the intervention of an adjudicator was recently considered in Law Society of Upper Canada v. West. ${ }^{76}$ The Law Society Appeal Tribunal held that the original panel had not entered into the fray by directing notice of the proceeding to a third party:

By directing that notice be given, the hearing panel did not undermine the appearance of fairness or create a reasonable apprehension of bias. Directing notice as a result of reputational interests being engaged provided no indication as to the hearing panel's view as to whether Mr. West's evidence should or would be accepted - only that the evidence, if accepted, could put Mr. Ducharme's reputation at risk. In directing that notice be given, the hearing panel was not advancing the interests of either party but addressing the reputational interests of a person not before the panel. ${ }^{77}$

See e.g. RDS, supra note 27 at paras 50-59.

See e.g. Wagar, supra note 64 (the trial judge's interventions in a sexual assault case betrayed reliance on discredited sexual stereotypes and myths); Bush, supra note 69 (the trial judge's unsubstantiated assertion that an expert witness's testimony disputing the accuracy of municipal records amounted to an allegation of fraud on the part of the defendant municipality gave rise to a reasonable apprehension of bias); $R v$ Burdett, 1993 ABCA 379 (CanLII) (the trial judge's refusal to accept a guilty plea and the statement that "the system had been put to a waste on a set of facts like that" gave rise to a reasonable apprehension of bias at para 2).

See Metis Child, supra note 57 at paras 51-53; The Honourable Madam Justice Jennifer Blishen, "SelfRepresented Litigants in Family and Civil Law Disputes" (2006) 25 Can Fam LQ 117. Justice Blishen, writing extra-judicially, has acknowledged that a greater degree of intervention may be required in family law proceedings to ensure the best interest of the child. 2015 ONLSTA 11, 2015 ONLSTA 11 (CanLII).

Ibid at para 40 . 
The appeal panel considered three ways in which the third-party notice may have "entered into the fray": interference with the adversarial process, undermining the appearance of fairness, and creating a reasonable apprehension of bias. It rejected all three on the basis that the notice was not prejudicial to the appellant. ${ }^{78}$

In Schmaltz, the Court agreed that the trial judge had a duty to protect the complainant from overly aggressive or irrelevant cross-examination. ${ }^{79}$ This suggests that judicial interventions may be justified even in criminal cases if they secure the interests of parties who lack direct means of asserting them. Arguably, the Crown could have objected to irrelevant lines of questioning in Schmaltz and it was the absence of a Crown objection that led to the need for the judicial intervention. ${ }^{80}$ The trial judge was put in the uncomfortable situation of either quietly witnessing irrelevant cross-examination of the complainant or being seen to impermissibly interfere with the right of the accused to a fair trial. Had the Crown objected, all the trial judge would have had to do was rule on the objection, a situation much less likely to cause bias concerns. That said, the Crown is in a tricky situation because the right to full answer and defence typically translates into a robust right of the defence to cross-examine the complainant and Crown interference with that right may give rise to Canadian Charter of Rights and Freedoms concerns. ${ }^{81}$

In Schmaltz, the context of the interventions of the trial judge could be seen to be analogous to that in child protection proceedings in that the interests of a litigation participant who is not represented are at stake. However, as in the case of the Crown, the court's ability to intervene will still be restrained by the right of the accused to make full answer and defence. At the same time, the Supreme Court of Canada accepted in $R v$. Mills ${ }^{82}$ that the complainant's rights to privacy sounded under section 8 of the Charter. Both impartiality and trial fairness demand that these interests be reconciled rather than allowing one to trump the other.

\section{Areas of Continued UnCERTAinty}

\section{A. Interventions for the Purposes of Assistance}

The issue in Hazelton Lanes and Schmaltz was not merely whether the judicial interventions betrayed a predetermined preference for one side over another, but whether the judge was actively helping one side in a way that was inappropriate. This concern has particular resonance in the context of active adjudication because that approach presumes that some forms of assistance are appropriate, and the issue is how to draw the line between appropriate and inappropriate assistance.

\footnotetext{
$78 \quad$ Ibid at para 39.

79 Supra note 19 at para 47

${ }_{80}$ We acknowledge that there is also a neutrality requirement applicable to the Crown: $R v$ Boucher (1954), [1955] SCR 16. However, it appears that it is both parliamentary intent and sound criminal justice policy that courts work towards making hearings safer for sexual assault complainants. Thus, Crown neutrality does not, in our view, require that Crowns remain silent when a sexual assault complainant is exposed to irrelevant, rape mythological, and potentially abusive questioning. See Woolley, supra note 64.

81 Part I of the Constitution Act, 1982, being Schedule B to the Canada Act 1982 (UK), 1982, c 11 [Charter]. See e.g. $R v$ Lyttle, 2004 SCC 5, [2004] 1 SCR 193 at para 2; $R v$ WL, 2015 ONCA 37, 123 OR (3d) 641.

$82 \quad$ [1999] 3 SCR 668.
} 
This has sometimes proven difficult. ${ }^{83}$ Generally speaking, assistance in explaining the process, particularly to self-represented litigants, has tended to pass appellate muster, but assistance usurping the role or compensating for the shortcomings of counsel, has not. In Davids, the Ontario Court of Appeal noted that fairness requires decision-makers to "attempt to accommodate unrepresented litigants' unfamiliarity with the process so as to permit them to present their case. $"{ }^{84}$

By contrast, in Wagner v. Saskatchewan Wheat Pool, the Saskatchewan Court of Appeal overturned the decision of the trial judge in a pension benefits case where the trial judge had taken the initiative to have the pleadings amended.$^{85}$ The trial judge had done so out of concern that counsel for the respondent had not been careful in crafting the pleadings and had made a careless omission. The Court of Appeal agreed that there was an obligation on trial judges to go beyond the role of passive bystanders to trial proceedings. However, the Court cautioned that trial judges should not attempt to compensate for the real or perceived failings of counsel.

Appellate courts have been more probing of judicial intervention in cases involving represented parties than those involving self-represented litigants. ${ }^{86}$ The Federal Court has recognized that it is a reversible error not to assist self-represented litigants. In Dhaliwal, the Court held that:

Decision-makers have an obligation to ensure that the self-represented litigant understands the nature of the proceedings, and to direct the litigant's attention to salient points of procedure: Wagg v. Canada... That did not happen here. Indeed, it appears that the presiding member did not himself understand the procedural options available when an individual appearing without counsel wished to give evidence on his own behalf. $^{87}$

However, the duty to assist self-represented litigants does not extend to adopting an inquisitorial mode of hearing, even in administrative proceedings. One self-represented litigant challenged an eviction notice before the Saskatchewan Court of Queen's Bench on the basis that the adjudicator had not sufficiently inquired into the personal circumstances of the applicant and had failed to ask questions of him. In rejecting the application, the Court noted that it was not the job of the adjudicator "to investigate or probe factual matters, or ... mediate the dispute." 88 The Court went so far as to suggest that it would have been an error of law if the adjudicator had taken a more active role in advancing the case of the applicant. ${ }^{89}$ It appears that the scope of the duty to assist self-represented or marginalized litigants is not entirely certain.

For an interesting discussion on the ongoing uncertainty of the degree of appropriate assistance to self represented litigants in the United States, see Mark Andrews, "Duties of the Judicial System to the Pro Se Litigant" (2013) 30:2 Alaska L Rev 189.

Davids, supra note 39 at para 36.

2005 SKCA 153,275 Sask R 150 at paras 14-15.

Professor Lee Stuesser reminds us that not all pro se accused are the same and advocates for a contextual approach to determining the level of assistane that is required and appropriate in a particular case: Lee Stuesser, "Dealing with the Un-represented Accused" (2003) 9 Criminal Reports (6th) 82.

Dhaliwal, supra note 39 at para 15 [citation omitted].

Cheon v Altern Properties Inc, 2015 SKQB 23, 468 Sask R 13 at para 31.

Ibid. 
In Hazelton Lanes, the Court of Appeal was concerned about the trial judge's mid-trial order for the production of documents. In the view of the Court of Appeal, most of the documents being sought were designed for use in challenging the personal defendant's general credibility and were of doubtful relevance to the issues at the trial. To the extent that they were of relevance to the credibility of the personal defendant in respect of the matters at issue in the trial, a more modest order for the production of documents would have been appropriate. The Court of Appeal took the view that the trial judge effectively allowed the cross-examination of the personal defendant to be turned into "a judgement-debtor examination." ${ }^{90}$ As a result, the Court concluded that "[i]n effect, the trial judge aligned himself with the [plaintiffs] on the production issue and lost all sense of what was proportionate and necessary to preserve trial fairness and efficiency." 91

Occasionally, judges have sought alternatives to assisting self-represented litigants because of bias issues or have expressed concern that the assistance they did provide was uncomfortably close to the line. For example, in a charge involving a speeding ticket, the Manitoba Provincial Court in R. v. Hykawy (RA) held that the Crown's evidence was inadmissible and thus it had not made out its case. ${ }^{92}$ This followed a series of judicial interventions pursuing a number of lines of inquiry that had not been raised by the selfrepresented accused. The judge expressed concern in this case that he had to get into the arena or had entered the fray. ${ }^{93}$ Alternatives to judicial assistance of self-represented litigants in criminal cases may include ordering a conditional stay of proceedings or court-appointed counsel. This is appropriate when the trial judge in a criminal proceeding comes to the conclusion that it is no longer possible to afford the accused a fair trial while avoiding a situation where the trial process would be tainted by the appearance of bias because the judge is essentially acting as the counsel of the accused. ${ }^{94}$

\section{B. Cumulative Factors}

The jurisprudence is generally clear that the factors set out above are cumulative in the sense that the presence of more than one factor can contribute to an overall finding of a reasonable apprehension of bias, even if one factor alone might not be sufficient to overcome the presumption of impartiality. However, it is less clear whether appellate courts will treat these various factors as cumulatively meeting the burden of proof or whether courts will engage in a balancing exercise after a holistic view of the trial. One view is that once the party who is alleging a reasonable apprehension of bias has satisfied the onus of overcoming the presumption of impartiality, the evidence of other indicia supporting the trial judge's impartiality will not be capable of restoring a finding of impartiality. An example of this approach is R. v. Simpson ${ }^{95}$ which involved fishing in a closed zone. The Nova Scotia Supreme Court sent the matter back to trial because the trial judge had repeatedly intervened in the trial and, in the context of the seizure of an essential piece of equipment, expressed the hope that the accused would not need the piece of equipment following the trial, clearly implying an expectation that the accused would be convicted. Unsurprisingly, this was

Hazelton Lanes, supra note 13 at para 88.

Ibid at para 82 .

2007 MBPC 1, 211 Man R (2d) 98.

Ibid at para 20 .

$R v$ McKay, 2010 BCPC 92, 2010 BCPC 92 (CanLII).

(1997), 158 NSR (2d) 314 (SC). 
thought to give rise to a reasonable apprehension bias. The court considered a number of instances throughout the trial as indicators for the reasonable apprehension of bias: the frequency of the interventions, the one sidedness of the interventions, cutting off questions, presuming to know what witnesses would say if allowed to answer, and the use of speculation to fill gaps in the evidence.

By contrast, some appellate courts have cautioned not to consider judicial interventions in isolation, but rather take a holistic view of the trial as it unfolded. In Hazelton Lanes, the Ontario Court of Appeal indicated that if the comments made during cross-examination were considered in isolation, they "could be viewed as reflecting nothing more than a trial judge's exasperation with a difficult witness." 96

The Court went on to adopt a cumulative factors approach. It noted that when considered in light of the trial judge's other actions, the judicial interventions contributed to the conclusion that the trial judge had prejudged the personal defendant's conduct and credibility. These other actions included the trial judge suggesting that the plaintiffs bring an application for a Mareva injunction partway through the trial ${ }^{97}$ and making findings in his subsequent reasons for granting the injunction that went beyond stating that the evidence established a prima facie case. This effectively prejudged a number of issues in the case. ${ }^{98}$

With respect to the trial judge's interactions with the personal defendant, the Court of Appeal was concerned that the tenor of the questions and comments would lead a reasonable person to believe that the trial judge was committed to a particular view of the personal defendant and his evidence before his testimony had been completed. The trial judge's procedural rulings reinforced the Court of Appeal's view that a reasonable observer would conclude that the trial judge had allowed his frustration with the personal defendant's testimony and conduct to influence his judgment to the point where he was no longer giving impartial consideration to the issues before him.

At the same time, the Court in Hazelton Lanes seems to have allowed for the possibility that a holistic view of the trial could, in some circumstances, impact the bias analysis in the sense that partiality concerns could be attenuated by pointing to countervailing aspects of the trial. This discussion occurred in the context of a question regarding whether a full transcript had to be prepared before an appeal alleging bias evinced by judicial interventions could be heard. The Court of Appeal proceeded without a full transcript. Counsel for the respondent argued that this prevented the Court from placing the trial judge's actions in their entire context.

The Court of Appeal acknowledged that it is normally necessary to examine the record in its entirety in order to assess whether a trial judge's conduct gave rise to a reasonable apprehension of bias. ${ }^{99}$ In this instance, however, the respondents did not identify specific material from the balance of the trial that would justify those actions of the trial judge that 
were called into question. Thus, the Court of Appeal was satisfied that the material before it was sufficient to make an assessment of the trial judge's conduct in the hearing. ${ }^{100}$

It seems to us that it would be beneficial to clarify when bias concerns could be cured by taking a holistic view. In every case, judicial interventions should be considered in their context. It is widely recognized that transcripts can only do so much to capture the true tone of a proceeding. This includes judicial interventions. Even acknowledging the limitations, courts should be loath to find a reasonable apprehension of bias on a snippet view of the proceeding. Instead, all interventions have to be reviewed contextually. That said, one factor that is clearly subject to correction by taking a holistic view is the evaluation of onesidedness of judicial interventions. The timing and frequency analysis will also benefit from taking a big picture view, but only in the sense that the absolute number of interventions is less indicative than the number of interventions compared to the length of the trial. The other factors are, in our view, less susceptible to a balancing analysis.

\section{BEYOND BIAS}

The role of trial judges and administrative tribunal members in civil and administrative proceedings has been appropriately expanding, and while the precise boundaries of judicial interventions remain contested, there can be no question that effective, accessible, and efficient adjudication may require a certain degree of activism on the part of the adjudicator. ${ }^{101}$ The matter is even more complicated in criminal proceedings. The fair criminal trial is different than the fair civil or family trial in the sense that the criminal trial lacks procedural symmetry between the parties. The criminal trial is the paradigmatic instance of the adversarial process and its integrity is highly dependent on protecting the rights of the accused in the face of the overwhelming resource advantage the Crown has in the vast majority of cases.

The decision in Schmaltz is interesting because it suggests the existence of a duty on the part of the judge to protect the witness in a sexual assault case from inappropriate questioning. It further suggests that this duty militates against a finding of bias arising from interventions since this sort of assistance is not only appropriate but part of the judge's duties. That said, the majority's conclusion that the judge had interfered with the ability of the accused to make fair answer and defence suggests that, at least in criminal cases, it will not be enough for the judge's intervention to pass the legal test for impartiality. Additionally, the evidentiary limitations on evidence relating to the character of the accused may impose a separate set of considerations. For example, the Nova Scotia Court of Appeal in Kilburn overturned a conviction because the trial judge had questioned the accused in a manner that exceeded the scope of the examination-in-chief and the cross-examination. This impugned the character of the accused. ${ }^{102}$ excessive focus on efficiency may imperil trial fairness: Honorable Annette J Scieszinski, "Not on My Watch: One Judge's Mantra to Ensure Access to Justice" (2013) 61:3 Drake L Rev 817 at 829. Kilburn, supra note 10. 
Leaving aside the question of whether the majority or the minority was right on this point in the context of the Schmaltz case itself, it could be argued that the logic of the case is not confined to criminal matters. In other words, it seems possible to suggest that a judge's intervention or assistance to one party does not give rise to a reasonable apprehension of bias because the judge is providing a type of assistance that is generally appropriate, and at the same time argue that the judge's intervention prevented a party from fairly presenting its case and therefore violated the hearing rights branch of the fairness doctrine. As noted above, it is instructive that the majority in Schmaltz relied on the presumption of impartiality in reaching the conclusion that the trial judge's actions did not give rise to a reasonable apprehension of bias but was not prepared to acknowledge the existence of a similar presumption of fairness when the issue was whether or not the trial judge had improperly interfered with the ability of the accused to make a fair answer.

\section{Conclusion}

The situations that arose in Hazelton Lanes and Schmaltz are not isolated phenomena. Each case in which a trial judge's conduct is challenged on the basis of a reasonable apprehension of bias presents a unique situation, and the Supreme Court of Canada has cautioned that application of the reasonable apprehension of bias test is highly factspecific. ${ }^{103}$ Nevertheless, it seems to us that there is a pattern to the type of bias cases of which Yukon, Hazelton Lanes, and Schmaltz are illustrations. It is a pattern in which a trial judge becomes frustrated with a party to the litigation (or their counsel) and displays this frustration in a way that would leave the impression in the mind of a reasonable observer that the judge has predetermined the outcome of some important aspect of the case. These cases also illustrate that the sources of judicial frustration are often closely related to the very objectives of case management and active adjudication: behaviour on the part of litigants and counsel that tends to undermine accessible, efficient, and effective adjudication. We conclude by offering some suggestions.

\section{A. THERE IS ROOM FOR CHANGE}

From the discussion provided in this article, it might seem that the safest course for a trial judge is to avoid any intervention in the proceedings and to sit impassively as the parties present their evidence and submissions. While this may be attractive as a strategy for avoiding complaints about lack of impartiality, it may not be a viable strategy for ensuring that appropriate use is made of court time.

Appellate courts have encouraged changes to the adversarial trial that tend to advance accessibility and efficiency. We find the following passage from the Ontario Court of Appeal's decision in Felderhof particularly significant in considering the appropriateness of judicial intervention to ensure that trials proceed in an orderly and efficient manner:

Whatever may have been the case in the past, it is no longer possible to view the trial judge as little more than a referee who must sit passively while counsel call the case in any fashion they please. Until relatively recently a long trial lasted for one week, possibly two. Now it is not unusual for trials to last for many months, 
if not years. Early in the trial or in the course of a trial, counsel may make decisions that unduly lengthen the trial or lead to a proceeding that is almost unmanageable. It would undermine the administration of justice if a trial judge had no power to intervene at an appropriate time and, like this trial judge, after hearing submissions, make directions necessary to ensure that the trial proceeds in an orderly manner. I do not see this power as a limited one resting solely on the court's power to intervene to prevent an abuse of its process. Rather, the power is founded on the court's inherent jurisdiction to control its own process. ${ }^{104}$

In a similar vein, the Federal Court rejected a challenge of a decision of the Refugee Board on the basis that the panel member had taken over the questioning of a witness: "Neither RPD members nor judges are required to sit in monk-like silence throughout a proceeding. It is more than legitimate for a member to ask questions to clarify testimony or to address issues which are relevant to the RPD's determination." 105

Thus, judges and administrative decision-makers are encouraged to take more of a handson approach than has traditionally been thought to be appropriate. In particular, courts have encouraged steps that promote shorter trials, enhanced participation of self-represented litigants, and interventions that compensate for the vulnerabilities of third parties.

\section{B. PARTY EXPECTATIONS ARE IMPORTANT}

Much of case management and active adjudication represents a shift in control away from the parties and their counsel and towards adjudicators. It is not surprising that this meets with some resistance. The impacts will be felt most acutely in those areas where parties have traditionally exercised most control. It appears not accidental that both of our key cases raise difficult bias and trial fairness issues in the context of judicial interventions in crossexaminations, a place of maximum party control in the adversarial trial. Parties may be more tolerant of active adjudication in those elements of a proceeding where they do not expect to exercise as much control (as in direct examination), while parties may be more sensitive to interventions in those elements where parties have traditionally controlled the process. This suggests that judges should expect resistance to interventions that reach into these high control areas.

\section{MANAGing EXPECTATIONS}

The rate of organizational change in the legal profession and in courts is very significant. Judges and lawyers are required to adjust their practices at an ever increasing rate. In this, they are not alone. In fact, the now vast literature on change management suggests that there are few certainties about change except that it is now ubiquitous and continuous. ${ }^{106}$ Case management and active adjudication represent a departure from the traditional way of doing business, and they are in themselves evolving. As locations of change, they are instances where litigants and legal professionals will encounter unexpected behaviour. The law societies, the Canadian Bar Association, the National Judicial Institute, and other continuing legal and judicial education organizations have been appropriately alert to this arena of 
change and have provided some much needed opportunities for continuing legal education. Beyond these, it appears useful to provide information about the conduct of a hearing to litigants at the outset. This is particularly important in matters involving self-represented litigants, but is likely also useful in trials with counsel whenever the judge intends to depart from the traditional script of the adversarial trial. In this context, it is particularly important to remember that just because a judge has used a particular mode of trial for a few years, this does not mean that all litigants will be familiar with it. Judges in smaller jurisdictions may be able to establish a shared understanding of changed practice more quickly, but in many cases judges will have to proactively engage with parties and counsel about the intended conduct of the hearing for some time to come.

\section{AVOIDING OVERREACH}

Judges hold significant procedural power in the courtroom, but it is not unlimited. The cases under consideration suggest to us that one of the ways in which active adjudication can go off the rails is when judges attempt to do too much. It is appropriate to encourage the parties to be efficient, but it may be counterproductive to strong-arm them into efficiency. It is appropriate for judges to assist self-represented litigants, but judges cannot singlehandedly solve the profound disadvantage that accrues to unrepresented parties. Our system is built on the lawyered trial and while a large number of self-represented litigants requires modifications in court procedure, judicial interventions in individual cases will not be able to bring about systemic change. It is appropriate for judges to seek to protect the interests of third parties, but judges are not in a good position to rebalance the rights of the accused to make full answer and defence with the rights of sexual assault complainants. Judges should absolutely seek to protect complainants from abusive and discriminatory questioning, but should only be able to do so within the scope of existing rape shield laws. A robust implementation of these laws is possible, but their judicial expansion is not.

\section{E. The CaSe for Rule-Based Change}

Finally, it is instructive in our view to note that successful challenges to judicial impartiality based on a concern that a judge engaged in active adjudication has descended into the fray during the course of a trial seem to be more frequent than successful challenges based on the knowledge case management judges or masters have acquired about the parties during the proceedings. ${ }^{107}$ In part, this may reflect a more general reluctance to accept bias arguments based on prior knowledge of the parties that may be, to some extent at least, inevitable for judges dealing with "repeat customers." 108 However, authorization of case management activity through procedural rules and attention paid in the course of developing rules governing meditation could compromise the parties' perception of the judge's impartiality if the same judge is to try a case after a failed mediation attempt. If active

While Canadian courts have generally taken a fairly robust view of the ability of judges to make interlocutory rulings and subsequently maintain an appearance of impartiality, some Australian jurisprudence has been less sanguine. We are of the view that the Canadian approach is preferable. In particular, we agree with Anna Olijnyk that a highly sensitive application of the reasonable apprehension of bias test undervalues the importance of efficiency and timeliness to litigants and the administration of justice generally: see Anna Olijnyk, "Apprehended Bias and Interlocutory Judgments" (2013) 35:4 Sydney L Rev 761 at 776-77.

108 See e.g. Newfoundland and Labrador (Director of Child, Youth and Family Services) v Thorne, 2007 CanLII 52943 (NL Prov Ct). 
adjudication is based on a trial judge's inherent authority to control proceedings, it is not benefitted from explicit authorization from rules or general deliberation in a rule-making forum about how best to balance demands for fairness, impartiality, simplicity, efficiency, proportionality, and sustainability that may be in competition with each other. This is not to say that judicial efforts to expand the scope of active adjudication in the absence of explicit rules authorizing such techniques are bound to fail, but they are likely to be constrained in their development by our traditional ideas of impartiality and fair procedure. In our view, the goals identified in reports such as Access to Civil \& Family Justice: A Roadmap for Change are unlikely to be accomplished without significant changes to our approach to adjudication. ${ }^{109}$ We have serious doubts that incremental change through the common law of active adjudication is sufficient. 